\title{
FAKTOR-FAKTOR YANG MEMPENGARUHI KebERHASILAN Penataan Pkl Sebagai Strategi Penataan Ruang Kota SURAKARTA
}

\author{
MURTANTI JANi RAHAYU ${ }^{1}$ \\ Program StUdi PERENCANAAN WilAyah DAN Kota \\ FAKULTAS TEKNIK \\ UNIVERSITAS SEBELAS MARET, SURAKARTA \\ EMAIL: MJANIRAHAYU@GMAIL.COM \\ RR. RATRI WERDININGTYAS ${ }^{2}$ \\ Program StUdi PERENCANAAN WilAyah DAN Kota \\ FAKULTAS TEKNIK \\ UNIVERSITAS SEBELAS MARET, SURAKARTA \\ MUSYAWAROH ${ }^{3}$ \\ PROGRAM STUdi PERENCANAAN WILAYAH DAN KoTA \\ FAKULTAS TEKNIK \\ UNIVERSITAS SEBELAS MARET, SURAKARTA
}

\begin{abstract}
Hunger and poverty countermeasure was appointed to be the first target in the Millennium Development Goals (MDGs) global mandate. It is relevant with Indonesia's condition in the last three years in which the amount of poverty-stricken people grew significantly. To boost the population's economy to a sustainable level, Solo's City Government try to give more space to the informal sectors in the city. This policy doesn't aim to improve the economy quantitatively but also equitably by facilitating the informal sectors, so that they can compete with the formal sectors that are dominated by the "big companies" as in nearly every big city in Indonesia.

One of the growing informal sectors is the street vendors. Relocation and stabilization are the two programs run by the Surakarta government to give a better chance for the street vendors to survive the competition with the formal sectors. Hundreds even thousands of street vendors in Solo has been regulated to empower the city's local economy. The factors that influence the success of the street vendor regulation isn't only perceived from the city's aesthetics, which always became the main reason, but also perceived from the quality growth in activity performance after the program has been done to ensure sustainability.

The success of the street vendor regulation must be seen from the street vendor's perspective. Unique character and street vendor behavior that vary richly must be known to ensure the street vendors can accept the planned program. In order to point out the location character role in the city's spatial arrangement strategy, the focal point of this research is exploring the factors that influence street vendor regulation adjusting with the needs and demands of street vendors
\end{abstract}

Keywords: location character, stabilization, relocation

\section{PENDAHULUAN}

Menurut Peraturan Daerah Kota Surakarta No. 3 Tahun 2008 tentang Pengelolaan Pedagang Kaki Lima, yang dimaskud PKL adalah pedagang yang menjalankan kegiatan usaha dagang dan jasa non formal dalam jangka waktu tertentu dengan mempergunakan lahan fasilitas umum yang ditentukan oleh Pemerintah Daerah sebagai tempat usahanya, baik dengan menggunakan sarana atau perlengkapan yang mudah 
dipindahkan, dan/atau dibongkar pasang.

Urbanisasi dan modernisasi akan mendorong adanya perkembangan masyarakat yang tidak seimbang. Perkembangan yang dimaksud antara lain terkait kesejahteraan masyarakatnya. Selanjutnya sektor informal muncul sebagai produk dari proses urbanisasi dan modernisasi yang belum selesai (Soetomo, 2009). Kehadiran sektor informal di dalam perkotaan merupakan respon dari adanya pendatang dan masyarakat miskin kota terhadap pembangunan yang tidak merata, urbanisasi, meluasnya tingkat pengangguran dan merebaknya tekanan kemiskinan. Ketika modernisasi yang mendorong perkembangan kota dan peningkatan kesejateraan masyarakat tidak diimbangi dengan berbagai fasilitas public dan kesempatan kerja yang memadai bagi kaum urban maka mereka akan mengalami kesulitan dalam meningkatkan kesejahteraannya (Jellinek, 1995). Lebih lanjut, menurut beberapa pakar (Bintarto 1989, Evers 2002, Alisjahbana2006, Soetomo 2009) beberapa kondisi yang menyebabkan kehadiran sektor informal di perkotaan terus bertambah meluas dipengaruhi oleh kekuatan penarik yang berasal dari kota dan kekuatan pendorong yang berasal dari desa. Selengkapnya penyebab tersebut adalah sebagai berikut. Pertama, terjadinya segala fasilitas public sebagai bentuk konsentrasi investasi di perkotaan telah menarik masyarakat desa melakuan urbanisasi, namun jumlahnya melebihi lapangan pekerjaan yang tersedia, sehingga melahirkan pengangguran yang pada akhirnya mereka akan terserap di sektor informal kota yang bersifat ilegal, marginal, dan berskala kecil. Kedua, kondisi desa yang sangat rentan akibat paceklik, banjir, dan mundurnya sektor pertanian, serta padatnya penduduk, Ketiga, masyarakat pedesaan yang tidak terserap di sektor pertanian karena rendahnya pendapatan di sektor tersebut. Keempat, minimnya sumber daya alam dan material yang bisa dieksplorasi dan dibagi kepada penduduk pedesaan.

Pertumbuhan sektor informal terutama PKL, saat ini masih sulit untuk dikendalikan.Secara umum hal ini sering menimbulkan konflik (meski setiap kota intensitasnya berbeda) antara PKL dan pemerintah daerah akibat perbedaan persepsi saat ada penataan PKL. PKL merasa memiliki hak menempati wilayah tertentu karena ditarik retribusi. Karakter aktivitas mereka sangat beragam sesuai dengan jenis dagangan dan jenis sarana dagang yang bermacam-macam. Mc Gee and Yeung (1977) mengungkapkan PKL memiliki 4 jenis dagangan dan diperluas oleh Rahayu et al (2012) menjadi, jenis dagangan mentah, jenis dagangan makanan baik unprocessed maupun semi processed (di tempat atau dibawa pulang), non makanan dan jasa. Hal ini akan menentukan juga karakter berlokasi mereka, yang pada gilirannya harus dilakukan penataan oleh karena sering kali PKLdianggap mengganggu ketertiban tata kota karena selalu menempati lokasi-lokasi strategisdengan intensitas lalu lintas yang tinggi.

Untuk meminimalisasi konflik dalam penataan perlu diadakan pendekatan yang persuasif dengan mengetahui karakteristik mereka (wawancara Bapeda Sukoharjo 2008; Kasei Penataan PKL Kota Surakarta, 2012). Demikian halnya dengan kota Surakarta. Meski tidak menimbulkan konflik besar seperti yang terjadi di kota-kota lain, pemerintah kota Surakarta terus berupaya menekan jumlah PKL dengan konsep "Zero Growth Population" melalui berbagai bentuk penataan.

Pada penataan PKL di dalam Kota Surakarta pemerintah berwenang untuk menetapkan, memindahkan dan menghapus lokasi PKL dengan memperhatikan kepentingan sosial, ekonomi, ketertiban dan kebersihan lingkungan di sekitarnya. Pengelolaan 
atau sering dikenal dnegan tindakan penataan ini bertujuan untuk meningkatkan kesejahteraan PKL, menjaga ketertiban umum, dan kebersihan lingkungan. Dalam Mc Gee and Yeung (1977) beberapa tindakan penataan dikenal dengan istilah stabilisasi, relokasi dan pemindahan. Bentuk penataan yang diterapkan dikota Surakarta adalah stabilisasi dan relokasi (Rahayu e al 2012). Saat ini penataan bentuk stabilisasi paling banyak diterapkan di kota Surakarta dan menjadi preferensi dominan dari para PKL (Rahayu et al. 2012). Sedangkan relokasi diterapkan ketika keberadaan PKL di suatu tempat dianggap mengganggu dan perlu dipindahkan lokasinya di tempat lain. Hal ini seperti yang dilakukan terhadap PKL Monumen 45 Banjarsari dan PKL belakang kampus UNS serta PKL Jl. Dr. Rajiman. Dalam upaya penataan ini Dinas Pengelolaan Pasar tidak berkerja sendiri namun juga berkoordinasi dengan SKPD lain yang terkait (wawancaraKasi Penataan PKL, 2012).

\section{TINJAUAN LITERATUR DAN KONSEP}

\subsection{Karakter Berlokasi PKL}

Menurut McGee \& Yeung (1977:6364) bahwa PKL tidak berlokasi di seluruh ruang kota, menurutnya terdapat beberapa kecenderungan dari mereka dalam berlokasi, yakni : (1) PKL cenderung untuk berkonsentrasi pada area dengan kepadatan populasi yang tinggi pada titik-titik persimpangan transportasi, atau berdekatan dengan aktivitas-aktivitas seperti kompleks hiburan, pasar umum dan area komersial/perdagangan dimana mereka mendapat keuntungan dari produkproduk yang melengkapi dan tarikan konsumen secara bersama.(2) Kecenderungan berjualan pada area dengan komoditas yang sama (adanya bentuk cluster). Penelitian yang dilakukan di Hongkong dan kota-kota di
Asia Tenggara lainnya, mengindikasikan bahwa pola-pola konsentrasi komoditas PKL umumnya memiliki hubungan simbiotik dengan aktivitas retail yang berdekatan. (3) Keterkaitan dengan tipe unit usaha PKL dengan kecenderungan untuk berlokasi di pinggir jalan dan pintu masuk pasar dimana aliran pejalan kaki berada pada waktu puncak (peak hour). (4) Kecenderungan PKL untuk berada di wilayah dengan kepadatan populasi yang tinggi.

Pada umumnya PKL beraglomerasi pada simpul-simpul jalur pejalan yang lebar dan tempat-tempat yang sering dikunjungi orang dalam jumlah besar yang dekat dengan pasar publik, terminal, dan daerah-daerah komersial (Mc. Gee and Yeung, 1977). Kawasan yang dipilih PKL biasanya merupakan area kota yang mempunyai aktivitas ekonomi sangat produktif. Menurut paguyuban PKL (2012 dalam Rahayu et al 2012), lokasi yang diminati oleh sektor informal atau pedagang kaki lima antara lain : 1) Adanya kumpulan kegiatan dan kumpulan orang yang melakukan kegiatan bersama-sama pada waktu yang relatif sama; 2) berada pada kawasan tertentu yang merupakan pusat-pusat kegiatan perkotaan; 3) adanya kemudahan interaksi antara PKL dengan calon pembeli, meski dalam ruang yang sangat terbatas; 4) seringkali tidak memerlukan ketersediaan fasilitas dasar seperti air bersih dan listrik.

Dini Tri Haryati (2008) menerangkan terdapat beberapa faktor yang mempengaruhi lokasi kegiatan dagang PKL, yaitu: faktor Keramaian Lokasi, kemungkinan konsumen berbelanja tinggi, kenyamanan dan keamanan. Lokasi dagang PKL yang dianggap aman dan nyaman, yaitu lokasi yang bebas dari ancaman yang mengganggu. Seperti penertiban atau gangguan dari preman-preman.

\subsection{Bentuk Pengelolaan/Penataan PKL}


Di dalam RTRW Kota Surakarta tahun 2012-2030 pasal 40 ayat $g$, diamanatkan bahwa pemerintah harus menyediakan ruang bagi sektor informal. Artinya bahwa keberadaan PKL semestinya diakomodir di dalam tata ruang kota, sehingga tidak lagi muncul PKL di tempat-tempat yang tidak seharusnya diperuntukkan bagi PKL. Di dalam Pasal 3 Perda No. 3 tahun 2008 tentang Pengelolaan Pedagang Kaki Lima dinyatakan bahwa, lingkup dari Peraturan Daerah ini adalah semua kebijakan Pemerintah Daerah dalam rangka penataan, pemberdayaan, dan pengawasan serta penertiban PKL. Terkait lingkup penataan tempat usaha, pada pasal 4 ayat 2 disebutkan bahwa pemerintah berwenang untuk menetapkan, memindahkan dan menghapus lokasi PKL dengan memperhatikan kepentingan sosial, ekonomi, ketertiban dan kebersihan lingkungan di sekitarnya. Sebagai bentuk pengelolaan terhadap keberadaan PKL, penataan tersebut diatas bertujuan untuk meningkatkan kesejahteraan PKL, menjaga ketertiban umum dan kebersihan lingkungan.

Berdasarkan hasil observasi yang dilakukan oleh Rachbini dan Hamid (1994:90) dimana setiap berdirinya gedung baru selalu diikuti munculnya PKL berderet di sepanjang jalannya mengindikasikan bahwa keberhasilan pembangunan adalah ketika pembangunan fisik kota bersinergi dengan perkembangan ekonomi kerakyatan ini.

Menurut Mc. Gee and Yeung (1977) bentuk pengelolaan PKL ada 3 macam yaitu : Tindakan lokasional, Tindakan Struktural dan Tindakan Pendidikan. Tindakan lokasional adalah tindakan yang bertujuan mengatur pola lingkungan sekitar dari aktivitas PKL. Contoh tindakan ini adalah operasi pembersihan yang memindahkan PKL dari suatu area dimana mereka beroperasi. Tidak ada satu pemerintah pun yang membebaskan PKL untuk memilih lokasi berdagang sesukanya. Tindakan lokasional dapat dibedakan menjadi tiga tipe yaitu : relokasi, stabilisasi \& pemindahan. Tindakan struktural meliputi : perijinan, pembinaan dan bantuan/pinjaman. Tindakan pendidikan misalnya dengan memberikan training dan latihan management, ketrampilan serta pengetahuan tentang kebersihan operasi mereka.

\section{Metode Penelitian}

Pengumpulan data tentang PKL pada penelitian ini diperoleh dari observasi lapangan pada seluruh kawasan PKL di kota Surakarta dan kuesioner melalui proporsional sampling berdasarkan jenis dagangan. Untuk menjaga validitasnya, dilakukan triangulasi dengan pengurus Paguyuban PKL, para pakar dan narasumber dari SKPD terkait (Dinas Pengelolaan Pasar, DTRK, Bappeda dan DKP). Observasi dilakukan dengan bantuan borang observasi, untuk mencatat dan mengamati beberapa karakteristik PKL yang dicari (pemetaan lokasi PKL, jenis dagangan, bentuk sarana dagang, bentuk penataan).

Untuk mengetahui keterkaitan antara karakter berlokasi PKL dengan karakter aktivitasnya, metode penelitian yang digunakan adalah Deskriptif Kuantitatif menggunakan teknik analisis Crosstab. Untuk mengetahui kesesuaian Pengelolaan yang telah dilakukan oleh Pemerintah Kota dengan Karakter PKL, metode penelitian yang digunakan adalah Eksplanasi Kuantitatif menggunakan Cross Tab, Analisis T-test Berpasangan dan Analisa Faktor untuk mengelompokkan faktor-faktor yang berpengaruh.

\section{Hasil dan Pembahasan}

\subsection{Identifikasi Karakteristik PKL di Surakarta}


Kota Surakarta dikenal dengan program penataan PKL yang paling bersahabat. Kota Surakarta menganut konsep Zero Growth PKL, meskipun demikian jumlah PKL belum dapat dikendalikan. Dengan luas sekitar 44,04 $\mathrm{km} 2$, area kota Surakarta dipenuhi dengan keberadaan PKL. Telah dilakukan penataan pada beberapa lokasi yang sangat subur oleh PKL, dengan konsep stabilisasi dan relokasi, akan tetapi PKL terus tumbuh di sudutsudut kota menempati ruang-ruang publik yang tersisa.

Persebaran lokasi berdagang PKL di Kota Surakarta adalah sebagai berikut (Rahayu et al, 2012) : 1) PKL baru selalu muncul di dekat kegiatan-kegiatan ekonomi yang telah berkembang, dan biasanya tempat tersebut tidakdiperuntukkan bagi keberadaannya; 2) upaya penataan untuk mengakomodasi PKL pada ruang kota belum berhasil, jumlah PKL yang menempati lahan-lahan publik naik 34\% setelah mengalami penurunan cukup signifikan di tahun sebelumnya; 3) walaupun jumlah PKL yang ditata semakin banyak (sehingga berstatus legal), tetapi jumlah PKL yang menempati ruang publik juga meningkat. Karena belum ada alokasi tata guna lahan/peruntukan tertentu bagi PKL maupun tindakan tegas bagi pelanggaran penggunaan lokasi bagi PKL.

Sesuai dengan teori McGee and Yeung (1977) dan hasil observasi yang diperoleh bahwa jenis dagangan yang dijual oleh PKL diKota Surakarta adalah sebagai berikut :

1) Bahan mentah makanan dan makanan setengah jadi (buahbuahan, sayur mayur dan lainlain).

2) Makanan siap saji terbagi menjadi 2 yaitu :

a. PKL makanan siap saji di tempat (warung makan jawa, padang, gudeg) b. PKL makanan siap saji di bawa pulang (kripik, jus, gorengan)

3) Non makanan (baju, onderdil, HP, rokok,tanaman hias dan lain-lain).

4) Jasa pelayanan (tukang cukur, tambal ban, afdruk foto, tukang jahit/permak dan lain-lain).

Mereka didominasi oleh jenis dagangan makanan siap saji (siap saji di tempat dan siap saji di tempat lain). Berikut data dan persebaran PKL di kota Surakarta.

\subsection{Karakter Berlokasi PKL di Kota Surakarta}

Karakter berlokasi PKL adalah tabiat/perilaku/sifat PKL dalam mengambil tempat/lokasi (KBBI 2008). Ditunjukkan melalui cara bagaimana perilaku PKL mengatur diri/usahanya dan sekaligus terkait kondisi lokasi yang dipilihnya. Adapun variabel karakter berlokasi terdiri dari pola pengelompokan, sifat pelayanan, kedekatan dengan konsumen dan karakter lokasi yang diminati Sedangkan karakter lokasi adalah sifat atau kondisi yang dimiliki sebuah lokasi tertentu seperti lokasi yang dekat dengan aktivitas komersil, dekat dengan pusat kota, dekat dengan simpul transportasi/jalan utama, dekat dengan populasi penduduk yang padat , dekat dengan rumah tinggal pedagang, dekat dengan keramaian, ketersediaan fasilitas di lokasi (Rahayu et al 2012).Jadi karakter lokasi menjadi bagian dari karakter berlokasi.(Rahayu et al 2012)

PKL akan berlokasi mendekati aktivitas utama yang membutuhkan jasa layanan usaha yang ditawarkannya. Dari Rahayu et al (2012), alasan berlokasi PKL di Surakarta adalah : Di sekitar aktivitas perdagangan $(60,1 \%)$; di sekitar aktivitas rekreasi $(16,4 \%)$; di sekitar aktivitas pendidikan (13,7\%); di sekitar aktiitas perkantoran (6,6\%); di sekitar aktivitas kesehatan (3,3\%). Karakter berlokasi PKL dipengaruhi oleh karakter beraktivitasnya.

Karakter aktivitas PKL terdiri dari : luas tempat usaha, jenis sarana dagang, lama berdagang, waktu berdagang, 
jumlah kunjungan konsumen, asal konsumen (skala pelayanan), waktu transaksi tiap pembelian, golongan pengguna jasa, legalitas usaha (Rahayu et al 2012).

Dengan metode \& teknik analisis kuantitatif menggunakan crosstab dapat diketahui besaran pengaruh karakter aktivitas pada karakter berlokasi PKL sebagai berikut (Rahayu,2012) :

\section{a. Karakter Pengelompokan PKL}

Pola pengelompokan PKL (menurut McGee dan Yeung, 1977) :

1) Pola linier dipengaruhi oleh aktivitas utama di sepanjang jalan (seperti di Jl. Setiabudi, Jl. Agus Salim, Jl. Urip Sumoharjo, Jl. Sutarto, Jl. Surya, Jl. Juanda dan sepanjang Ring Road Mojosongo).

2) Pola mengelompok dipengaruhi keinginan PKL untuk melakukan pemusatan/PKL sejenis dengan sifat dan komoditas sama untuk lebih menarik minat pembeli (sekitar bangunan komersial, ruang terbuka, lapangan maupun taman, stasiun/terminal, pusat perbelanjaan, sekolah, RS, pasar, perkantoran dan lain-lain).

Adapun karakter pengelompokan PKL di Surakarta adalah sebagai berikut :

1) PKL yang cenderung berkelompok dengan dagangan sejenis adalah PKL makanan mentah, PKL bukan makanan dan PKL jasa pelayanan.

a) PKL bukan makanan yang cenderung berkelompok dalam melakukan usahanya

b) adalah yang memiliki skala pelayanan konsumen luas (Solo \& Luar Solo) dan juga yang memiliki harga dagangan per unitnya > Rp. 25.000,-

c) PKL Jasa pelayanan yang cenderung berkelompok adalah PKL yang memiliki harga jual per unit pelayanananya > Rp. 25.000,dan PKL yang memiliki jumlah waktu dagangan cukup lama $>6$ jam
2) PKL makanan siap saji di tempat memiliki pola yang sangat fleksible dalam berkelompok.

a) PKL makanan siap saji di tempat yang cenderung berkelompok adalah PKL yang memiliki karakter sebagai berikut : Membutuhkan luasan lahan dagang $>6 \mathrm{~m}^{2}$; memiliki waktu dagang tidak terlalu lama $<6$ jam; beroperasi di sore dan malam hari; memiliki jangkauan skala pelayanan luas (Solo dan Luar Solo); waktu transaksi per penjualan tidak lebih dari 20 menit; cenderung memiliki harga jual > Rp. 25.000,-.

b) PKL bukan makanan yang memiliki kecenderungan untuk bercampur dengan PKL dengan jenis dagangan lain adalah PKL yang menjual barang dengan harga murah dan PKL yang skala pelayanannya adalah konsumen local.

c) PKL jasa pelayanan yang memiliki kecenderungan tinggi untuk bercampur adalah PKL yang menjual pelayanan dengan harga murah dan PKL yang menjalankan usaha dagangnya lebih dari 6 jam sehari.

d) PKL makanan siap saji di tempat yang akan berpencar atau berkecederungan untuk bercampur dengan jenis dagangan lain adalah PKL yang memiliki luasanlahan tidak terlalu luas $\left(<6 \mathrm{~m}^{2}\right)$; menjalankan usahanya lebih dari 6 jam sehari; beroperasi di pagi dan siang hari; konsumen adalah masyarakat sekitar; waktu transaksi yang dubutuhkan konsumen tidak terlampau lama (hanya memenuhi kebutuhan akan makanan saja); memiliki harga jual barang murah (< Rp. 25.000,-).

Dari hasil pengamatan dan olah data pada $183 \mathrm{PKL}$, diperoleh data :PKL yg ingin bergabung dengan PKL dagangan 
sejenis sekitar 36\%.PKL yang ingin berkelompok dengan PKL lain jenis dagangan sekitar 26\% .Yang memilih bisa keduanya adalah $38 \%$.

\section{b. Karakter Sifat Pelayanan PKL}

Karakter sifat pelayanan PKL di Surakarta adalah sebagai berikut :

1) PKL dengan jenis dagangan bukan makanan lebih fleksible walaupun sebagian besar cenderung menetap pada suatu lokasi.

2) PKL yang memiliki sifat pelayanan berkeliling adalah PKL dengan jenis dagangan makanan siap saji di tempat lain.

3) PKL makanan siap saji di tempat dan jasa pelayanan cenderung menetap pada suatu lokasi dalam melakukan aktivitasnya dari awal hingga akhir. Beberapa PKL dengan jenis dagangan ini berpindah setelah beberapa waktu

Dari hasil analisis, yang mempengaruhi sifat pelayanan PKL adalah luas lahan dagang yang dibutuhkan, jenis sarana dagang, waktu berdagang dan waktu transaksi. Pola ini terlihat jelas pada PKL dengan jenis dagangan makanan siap saji di tempat:

1) Semakin luas lahan dagang yang dibutuhkan maka PKL akan cenderung untuk menetap di suatu lokasi.

2) PKL dengan sarana dagang warung tenda akan menetap, PKL dengan sarana dagang gerobak atau kereta dorong selain berkecenrungan menetap atau berpindah (menempati lokasi tertentu pada suatu waktu dan kemudian berpindah).

3) Waktu berdagang mempengaruhi sifat pelayanan. PKL yang melakukan aktivitasnya pada pagi dan siang hari akan cenderung fleksible untuk berkeliling, berpindah. Adapun PKL yang melakukan aktivitasnya di malam hari akan cenderung untuk menetap di suatu lokasi.

4) Semakin lama waktu transaksi yang dibutuhkan, maka PKL akan semakin berkecenderungan menetap pada suatu lokasi.

\section{c. Tingkat Kedekatan dengan Konsumen}

Dari hasil analisis dapat disimpulkan bahwa setiap PKL akan selalu berusaha mendekatkan lokasi berdagangnya dengan lokasi konsumen berada. Namun beberapa PKL memiliki pola khusus dimana PKL tidak selalu bisa mendekati lokasi konsumennya karena kondisinya.

1) PKL yang tidak bisa selalu menempatkan dirinya dekat dengan konsumen adalah PKL makanan siap saji di tempat $(28,1 \%)$ dan jasa pelayanan (52\%). Hal tersebut dipengaruhi oleh kondisi luasan dagang yang diusahakannya. Semakin luas lahan dagang yang diusahakan semakin fleksible. Semakin kecil lahan dagang yang dibutuhkan maka akan memudahkan PKL untuk mencari lokasi yang berdekatan dengan konsumen.

2) PKL makanan siap saji di tempat yang melakukan aktivitasnya pada pagi dan siang hari akan mencari lokasi berdekatan dengan konsumennya (28,7\%). Adapun PKL yang melakukan aktivitasnya pada sore dan malam hari lebih fleksible.

3) PKL yang sulit diatur adalah yang berkecenderungan menempati lahan berdagang mendekatkan dirinya dengan konsumen. PKL yang masih cukup bisa diatur karena fleksibilitasnya terkait dengan kedekatannya dengan konsumen adalah PKL dengan jenis makanan siap saji di tempat yang memiliki luasan dagang luas dan beropearsi di sore dan malam hari. PKL yang memiliki waktu dagang relative sedikit atau sebentar juga akan lebih 
mudah diatur dalam hal lokasi dibandingkan dengan PKL yang memiliki total waktu dagang lama (>6 jam sehari).

\section{d. Karakter Lokasi yang Diminati}

1) PKL secara teori akan selalu menempati lokasi-lokasi yang strategis yang bisa mendekatkan dirinya dengan konsumen dan melakukan penjualan sebanyakbanyaknya.

2) Dari fenomena PKL yang ada di Kota Solo masih banyak factor lain yang mempengaruhi pemilihan lokasi yang dilakukan oleh PKL seperti alasan khusus membutuhkan fasilitas pendukung, kenyamanan, visual yang baik dansebagainya.

Dari hasil analisis dapat disimpulkan terdapat perbedaan alasan pemilihan lokasi sebagai berikut :

1) PKL makanan siap saji di tempat, baik yang dikonsumsi di tempat atau dibawa pulang, pada umumnya memilih lokasi dimana terdapat fasilitas yang mendukung kegiatannya, misalnya ketersediaan air bersih, listrik, dansebagainya. Kestrategisan lokasi juga menjadi alasan yang cukup penting bagi jenis makanan siap saji di tempat selain alasan kebutuhan khusus.

2) Pada PKL makanan siap saji di tempat, semakin lama waktu berdagang dan semakin lama waktu transaksi yang diperlukan maka akan semakin banyak alasan yang dipertimbangkan dalam melakukan pemilihan lokasi.

3) PKL makanan siap saji di tempat yang melakukan operasinya di sore dan malam hari akan mempunyai lebih banyak pertimbangan dalam pemilihan lokasi berdagang.

4) Semakin mahal harga barang dagangan yang diperjualbelikan, akan semakin banyak pertimbangan dalam pemilihan lokasi selain kestrategisan lokasi.

5) PKL dengan jenis dagangan bukan makanan dan jasa pelayanan berkencenderungan memilih alasan kestrategisan lokasi sebagai alasan utama pemilihan lokasi.

6) PKL makanan mentah/setengah jadi bersifat fleksible tidak terpola secara khusus dalam alasan pemilihan lokasi.

\subsection{Pengaruh Karakteristik PKL pada Strategi Penataan Ruang Kota}

Sesuai dengan Perda No. 3/2008 bahwa tujuan penataan adalah dalam rangka meningkatkan kesejahteraan masyarakat. Bentuk penataan PKL yang dilakukan di kota Surakarta adalah stabilisasi dan relokasi. Stabilisasi membangun sarana dagang dan menetapkkan lokasi lama atau dekat dengan lokasi lama bagi PKL namun tidak mengubah status PKL menjadi pedagang formal. Relokasi memindahkan PKL ke dalam pasar sehingga merubah status PKL menjadi pedagang formal. Berikut hasil pengolahan untuk melihat perubahan PKL baik penataan stabilisasi maupun penataan relokasi PKL di kota Surakarta.

Penataan PKL di kota Surakarta tidak hanya dilakukan untuk membangun lapak PKL, namun juga terkait dengan pembangunan kelengkapan sarana dan prasarana, pembinaan SDM, bantuan modal, pendampingan dan pengaturan. PKL ditata dengan pendekatan yang sangat spesifik melalui mekanisme pendekatan personal, pendekatan lingkungan, kemudian pendekatan kelembagaan dan terakhir pendekatan formal/instansional.

Spesifikasi pendekatan tersebut adalah : Pendekatan nguwongke uwong, kemitraan, hati nurani dan saling menghormati. Selain karakter kepemimpinan yang santun dan memiliki komitmen tinggi terhadap ekonomi kerakyatan di kota Surakarta, 
komitmen seluruh stakeholders kota menjadi kekuatan pendukung dalam mengurai permasalahan PKL.

Dari hasil analisis karakter berlokasi PKL diatas diharapkan dapat dipergunakan sebagai salah satu strategi penataan ruang kota melalui langkah sebagai berikut :

1) Karakteristik kebutuhan berlokasi PKL Non Makanan sesuai dengan Konsep relokasi.

a) Penataan PKL Non Makanan dengan konsep Relokasi (dipindahkan permanen) dikatakan berhasil dalam hal pengaturan dan peningkatan kualitas kawasan juga pemberdayaan ekonomi lokal (Pendapatan PKL meningkat).

b) Untuk kasus Pemindahan PKL dari Monumen 45 ke Semanggi, dapat dikatakan berhasil. PKL Non Makanan dengan Skala Pelayanan Kota, Harga > Rp. 25.000,-cenderung berlokasi "mengelompok" dengan PKL sejenis, "menetap", "tidak harus dekat dengan konsumen", "memiliki alasan khusus selain kestrategisan lokasi".

2) PKL Makanan Siap Saji ditata dengan konsep Stabilisasi (dibuatkan shelter di tempat yang sama) dikatakan berhasil dalam hal pengaturan dan peningkatan kualitas kawasan, akan tetapi tidak meningkatkan pendapatan (Pendapatan menurun).

Untuk kasus PKL : Dekat RS DKT, Solo Square, Manahan dan lainlain :

a) PKL makanan siap saji memiliki pola yang sangat fleksible dalam memilih lokasi usahanya.

b) Sifat pelayanan yang dekat dengan konsumen dan kebutuhan akan lokasi dipengaruhi oleh banyak hal. c) Tidak semua PKL makanan siap saji berkeinginan menetap dan berkelompok dengan jenisnya.

d) Tidak semua PKL yang distabilisasi meningkat pendapatannya.

e) Kecenderungan yang timbul, shelter stabilisasi ditempati oleh PKL baru.

\subsection{Faktor- Faktor Berpengaruh dalam Keberhasilan Penataan PKL}

Untuk menjadikan penataan PKL menjadi salah satu strategi pemberdayaan ekonomi masyarakat, maka perlu dicari faktor-faktor yang berpengaruh bagi keberhasilan penataan PKL tidak hanya dari sisi pengambil kebijakan tetapi juga dari sisi penerima, dalam hal ini PKL. Sebagaimana diketahui bahwa tujuan dilakukan penataan PKL adalah memberikan ruang yang lebih baik bagi PKL untuk berdagang sehingga diharapkan dengan adanya ruang yang baik akan mampu meningkatkan kinerja PKL. Oleh karena itu pengetahuan tentang faktor-faktor yang dianggap penting oleh PKL dalam sebuah penataan perlu untuk diketahui. Sehingga komponen dalam program penataan PKL yang dilakukan dapat tepat, efisien dan efektif memenuhi kebutuhan PKL. Sebagaimana temuan sebelumnya tidak semua penataan PKL yang berhasil secara fisik estetika juga berhasil sebagai program pemberdayaan ekonomi PKL. Hasil analisa pada sub bab ini akan menunjukkan faktor-faktor yang berpengaruh dalam keberhasilan penataan PKL menurut sudut pandang PKL sebagai pelaku. Analisa dilakukan dengan menggunakan teknik analisa faktor, sehingga akan diperoleh kelompok-kelompok faktor baru.

Terdapat 19 variabel penataan yang diuji sebagai faktor yang mempengaruhi keberhasilan PKL (Rahayu et al 2012) adalah 1). luas lapak PKL, 2).kondisi sarana dagang PKL, 3).pengaturan waktu pelayanan, 4).pola 
pengelompokan, 5). tingkat kestrategisan lokasi, 6).keterjangkauan transportasi, 7). kondisi sarana/fasilitas pendukung, 8).parkir, 9).penerangan, 10).air bersih, 11).pembuangan sampah, 12). estetika lingkungan, 13). kedekatan dg fungsi utama kota, 14). keamanan, 15). kebersihan, 16). pembinaan thd PKL, 17).legalitas, 18).aglomerasi dan 19).modal usaha.

\subsubsection{Stabilisasi}

Dari 19 variabel yang diujisebagai variabel yang mempengaruhi keberhasilan penataan stabilisasi diketemukan bahwa menurut PKL hanya ada 4 variabel yang memiliki pengaruh besar dalam keberhasilan stabilisasi PKL dari sudut pandang PKL, yaitu kondisi luas lapak, ketersediaan sarana pendukung, ketersediaan lampu penerangan dan pembinaan. Keempat variabel tersebut terkelompok menjadi 1 faktor dan mempengaruhi tingkat keberhasilan sebesar 63,2\%. Berikut ringkasan hasil analisa faktor 19 variabel berpengaruh terhadap keberhasilan stabilisasi PKL.

\subsubsection{Relokasi}

Dari 19 variabel yang diuji diketemukan 2 faktor yang tersusun dari 7 variabel yang memiliki pengaruh besar dalam keberhasilan relokasi PKL dari sudut pandang $\mathrm{PKL}$, yaitu kondisi sarana, kondisi pola pengelompokan, keberadaan fungsi utama dan aglomerasi untuk faktor 1 dan ketersediaan parkir, keteresdiaan air bersih dan estetika lokasi berkelompok membentuk faktor 2 . Kedua faktorini akan mempengaruhi tingkat keberhasilan sebesar $62,5 \%$ dari relokasi yang dilakukan. Berikut ringkasan hasil analisa faktor 19 variabel berpengaruh terhadap keberhasilan relokasi PKL.

\section{Kesimpulan}

1) Karakteristik PKL di Surakarta : a) Jumlah PKL harian 2.816 dan jumlah PKl mingguan 2.790.

b) PKL yang ada di Kota Surakarta didominasi oleh jenis dagangan makanan siap saji (siap saji di tempat dan siap saji di tempat lain).

c) PKL baru selalu muncul di dekat kegiatan-kegiatan ekonomi yang telah berkembang, jumlah PKL yang menempati lahanlahan publik naik 34\%.

2) Karakter berlokasi PKL terdiri dari :

a) Pola pengelompokan dalam berdagang (mengelompok, bercampur, fleksible).

b) Sifat pelayanan PKL (menetap, berpindah, berkeliling).

c) Kedekatan dengan konsumen dan

d) Karakter lokasi yang diminati (strategis, fasilitas dan sebagainya).

3). Karakter berlokasi PKL dipengaruhi oleh karakter beraktivitasnya. Karakter beraktivitas PKL terdiri dari : Luas Tempat Usaha, Jenis Sarana Dagang, Lama Berdagang, Waktu Berdagang, Jumlah Kunjungan Konsumen, Asal Konsumen (Skala Pelayanan), Waktu Transaksi Tiap Pembelian, Golongan Pengguna dan Jasa, Legalitas Usaha.

Keterkaitan antara karakter berlokasi PKL dengan karakter beraktivitas :

a) Karakter berkelompok :

- PKL yang cenderung berkelompok dengan dagangan sejenis adalah PKL makanan mentah, PKL bukan makanan dan PKL jasa pelayanan.

- PKL makanan siap saji di tempat memiliki pola yang sangat fleksible

b) Karakter Sifat Pelayanan PKL. 
- PKL dengan jenis dagangan bukan makanan lebih fleksible walaupun sebagian besar cenderung menatap pada suatu lokasi.

- PKL yang memiliki sifat pelayanan berkeliling adalah PKL dengan jenis dagangan makanan siap saji di tempat lain.

- PKL makanan siap saji di tempat dan jasa pelayanan cenderung menetap pada suatu lokasi dalam melakukan aktivitasnya dari awal hingga akhir.

Beberapa PKL dengan jenis dagangan ini berpindah setelah menetap beberapa waktu.

Dari hasil analisis, yang mempengaruhi sifat pelayanan PKL adalah luas lahan dagang yang dibutuhkan, jenis sarana dagang, waktu berdagang dan waktu transaksi.

b) Tingkat Kedekatan dengan Konsumen.

Dari hasil analisis dapat disimpulkan bahwa setiap PKL akan selalu berusaha mendekatkan lokasi berdagangnya dengan lokasi konsumen berada. Namun beberapa PKL memiliki pola khusus dimana PKL tidak selalu bisa mendekati lokasi konsumennya karena kondisinya.

c) Lokasi yang Diminati.

PKL akan selalu menempati lokasilokasi yang strategis yang bisa mendekatkan dirinya dengan konsumen, melakukan penjualan sebanyak-banyaknya dan alas an khusus lainnya membutuhkan fasilitas pendukung, kenyamanan, visual yg baik dan lain sebagainya.

4). Pengaruh karakter berlokasi PKL pada strategi penataan ruang kota adalah : a). Karakteristik kebutuhan berlokasi PKL Non Makanan sesuai ditata dengan Konsep relokasi dengan mempertimbangkan karakter lokasi seperti lokasi semula

b). Karakteristik kebutuhan berlokasi PKL Makanan Siap Saji apabila ditata dengan konsep Stabilisasi berhasil dalam halpengaturan dan peningkatan kualitas kawasan tetapi tidak meningkatkan pendapatan PKL .

\section{Daftar Pustaka}

Alisjahbana, 2006. Marginalisasi Sektor Informal Perkotaan. Surabaya:ITS

Bapeda Sukoharjo, 2008, Studi Penataan Pedagang Kaki Lima di Kabupaten Sukoharjo : Kabupaten Sukoharjo

Bintarto. 1989. Interaksi Desa-Kota dan Permasalahannya. Ghalia Indonesia

Evers, Hans-Dieter \& Korff, Rudiger. 2002. Urbanisasi di Asia Tenggara: Makna dan Kekuasaan dalam RuangRuang Sosial. Yayasan Obor:Jakarta

Departemen Pendidikan Nasional (2008). Kamus Bahasa Indonesia Pusat Bahasa. Jakarta. PT. Gramedia Pustaka Utama

D Rachbini dan Abdul H. 1994. Ekonomi Informal Perkotaan. Jakarta LP3ES

Haryanti, Dini Tri. 2008. Kajian Pola Pemnafaatan Ruang terbuka Publik Kawasan Bundaran Simpang Lima. Magister Teknik Perencanaan Wilayah dan Kota UNDIP. Semarang

Jellinek,L.1995. Seperti Roda Berputar:Perubahan Sosial Sebuah Kampung di Jakarta.Jakarta:LP3ES

Mc. Gee, T. G dan Yeung, Y. M. 1977. Hawkers In Southeast Asian Cities: Planning for The Bazaar Economy

Canada: International Development Research Centre.

Peraturan Daerah/Perda Kota Surakarta No. 3 Tahun 2008 Pengelolaan Pedagang Kaki Lima

Rachbini, D. dan Abdul H. 1994. Ekonomi Informal Perkotaan. Jakarta : LP3ES 
Rahayu. M.,J.,\& Kusumastuti, 2007, Identifikasi PKL Perkotaan di Kabupaten Sukoharjo, Universitas Sebelas Maret

Rahayu, M., J., Werdiningtyas, R., R., \& Musyawaroh, 2012, Strategi Pemberdayaan PKLSecara Partisipatif Dalam Mendorong Ekonomi Berkelanjutan Di Kota Surakarta, Penelitian Hibah Bersaing, PIPW LPPM UNS.

Soetomo, Sugiono, 2009. Urbanisasi dan Morfologi Proses Perkembangan Peradaban \&Wadah Ruang Fisiknya : Menuju Ruang Kehidupan yang Manusiawi. Graha Ilmu, Yogyakarta.

Lampiran

Tabel 1. Jumlah PKL di Kota Surakarta berdasarkan Jenis Dagangan

\begin{tabular}{|c|c|c|c|c|c|c|c|}
\hline No. & Kecamatan & $\begin{array}{c}\text { A=PKL } \\
\text { Makanan } \\
\text { Mentah/ } \\
\text { Setengah } \\
\text { Jadi } \\
\end{array}$ & $\begin{array}{c}\text { B=PKL } \\
\text { Makanan } \\
\text { Siap Saji } \\
\text { di } \\
\text { Tempat } \\
\end{array}$ & $\begin{array}{c}\mathrm{C}=\mathrm{PKL} \\
\text { Makanan } \\
\text { Siap Saji } \\
\text { di Tempat } \\
\text { Lain } \\
\end{array}$ & $\begin{array}{c}\text { D=PKL } \\
\text { Bukan } \\
\text { Makanan }\end{array}$ & $\begin{array}{c}\text { E=PKL } \\
\text { Jasa } \\
\text { Pelayanan }\end{array}$ & Jumlah \\
\hline 1 & Kecamatan Banjarsari & 10 & 339 & 152 & 145 & 103 & 749 \\
\hline 2 & Kecamatan Serengan & 2 & 173 & 62 & 79 & 6 & 322 \\
\hline 3 & Kecamatan Pasar Klwn & 0 & 329 & 183 & 47 & 51 & 610 \\
\hline 4 & Kecamatan Laweyan & 30 & 203 & 34 & 170 & 37 & 474 \\
\hline \multirow[t]{2}{*}{5} & Kecamatan Jebres & 3 & 328 & 118 & 49 & 60 & 558 \\
\hline & Jumlah PKL Harian & 45 & 1372 & 549 & 490 & 257 & 2.816 \\
\hline
\end{tabular}

(Sumber : Rahayu et al, 2012)

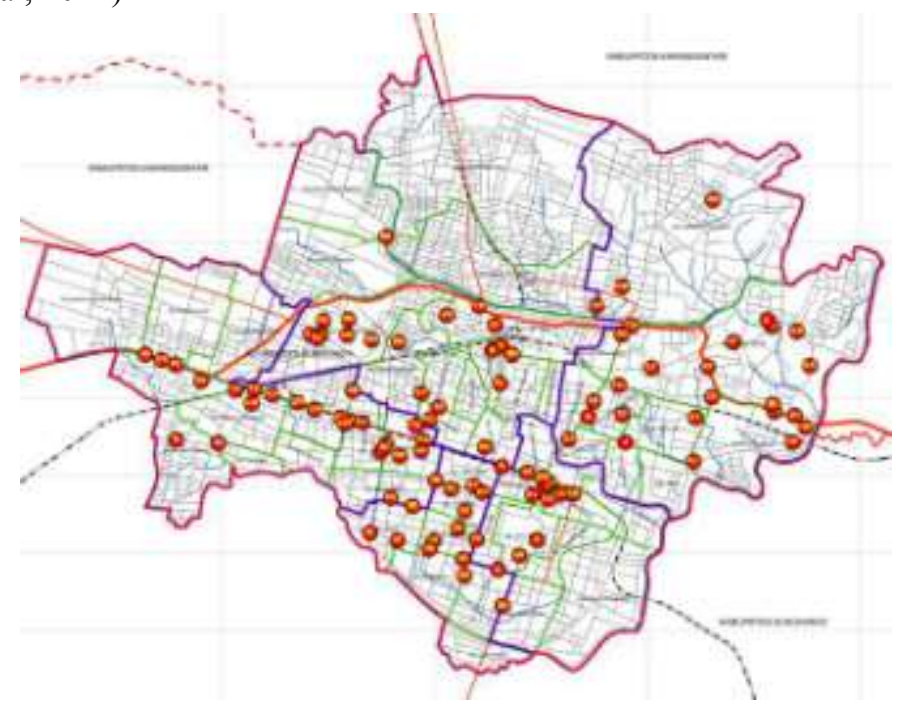


Gambar 1. Peta Persebaran PKL di kota Surakarta(Sumber: Rahayu et al 2012)

Tabel 2: Hasil Korelasi dan perubahan hasil Penataan Stabilisasi dan Relokasi

\begin{tabular}{|c|c|c|c|c|c|c|c|}
\hline \multirow[t]{2}{*}{ No. } & \multirow[t]{2}{*}{ Kondisi PKL } & \multicolumn{3}{|c|}{$\begin{array}{l}\text { Besarnya Korelasi dan Tingkat } \\
\text { Signifikansi Kondisi Sebelum dan } \\
\text { Sesudah Stabilisasi }\end{array}$} & \multicolumn{3}{|c|}{$\begin{array}{l}\text { Besarnya Korelasi dan Tingkat Signifikansi } \\
\text { Kondisi Sebelum dan Sesudah Relokasi }\end{array}$} \\
\hline & & $\begin{array}{l}\text { Koef. } \\
\text { Corr }\end{array}$ & Sig. & Analisis & $\begin{array}{c}\text { Koef. } \\
\text { Correlation }\end{array}$ & Sig. & Analisis \\
\hline 1. & Luas lapak & .422 & .020 & $\begin{array}{lr}\begin{array}{l}\text { Korelasi } \\
\text { kuat } \\
\text { signifikan }\end{array} & \text { dan } \\
\end{array}$ & .724 & .000 & $\begin{array}{l}\text { Korelasi kuat } \\
\text { dan signifikan }\end{array}$ \\
\hline 2. & Jam operasional & .942 & .000 & $\begin{array}{l}\text { Korelasi kuat, } \\
\text { dan signifikan }\end{array}$ & -.006 & .973 & $\begin{array}{ll}\text { Korelasi } & \text { tidak } \\
\text { kuat, dan } & \text { tidak } \\
\text { signifikan } & \end{array}$ \\
\hline 3. & Jumlah dagangan & . & . & - & . & . & - \\
\hline 4. & $\begin{array}{l}\text { Jumlah } \\
\text { pengunjung }\end{array}$ & .940 & .000 & $\begin{array}{l}\text { Korelasi kuat, } \\
\text { dan signifikan }\end{array}$ & 237 & .208 & $\begin{array}{ll}\text { Korelasi } & \text { tidak } \\
\text { kuat, dan } & \text { tidak } \\
\text { signifikan } & \end{array}$ \\
\hline 5. & Retribusi & .575 & .001 & $\begin{array}{l}\text { Korelasi kuat, } \\
\text { dan signifikan }\end{array}$ & -.349 & .058 & $\begin{array}{ll}\text { Korelasi } & \text { tidak } \\
\text { kuat, dan } & \text { tidak } \\
\text { signifikan } & \end{array}$ \\
\hline 6. & Pendapatan bersih & .594 & .001 & $\begin{array}{l}\text { Korelasi kuat, } \\
\text { dan signifikan }\end{array}$ & .943 & .000 & $\begin{array}{l}\text { Korelasi kuat } \\
\text { dan signifikan }\end{array}$ \\
\hline 7. & Keamanan & .719 & .000 & $\begin{array}{l}\text { Korelasi kuat, } \\
\text { dan signifikan }\end{array}$ & .075 & .695 & $\begin{array}{ll}\text { Korelasi } & \text { tidak } \\
\text { kuat, dan } & \text { tidak } \\
\text { signifikan } & \\
\end{array}$ \\
\hline 8. & Kualitas sarana & .538 & .002 & $\begin{array}{l}\text { Korelasi kuat, } \\
\text { dan signifikan }\end{array}$ & .257 & .171 & $\begin{array}{ll}\text { Korelasi } & \text { tidak } \\
\text { kuat, dan } & \text { tidak } \\
\text { signifikan } & \\
\end{array}$ \\
\hline 9. & Kebersihan lokasi & .381 & .038 & $\begin{array}{lr}\text { Korelasi } & \text { tidak } \\
\text { kuat, } & \text { dan } \\
\text { signifikan } & \\
\end{array}$ & -.002 & .991 & $\begin{array}{ll}\text { Korelasi } & \text { tidak } \\
\text { kuat, dan } & \text { tidak } \\
\text { signifikan } & \end{array}$ \\
\hline 10. & $\begin{array}{l}\text { Fasilitas } \\
\text { pendukung }\end{array}$ & .424 & .020 & $\begin{array}{lr}\text { Korelasi } & \text { tidak } \\
\text { kuat, } & \text { dan } \\
\text { signifikan } & \\
\end{array}$ & -.064 & .737 & $\begin{array}{ll}\text { Korelasi } & \text { tidak } \\
\text { kuat, dan } & \text { tidak } \\
\text { signifikan } & \\
\end{array}$ \\
\hline 11. & Peran PKL & .914 & .000 & $\begin{array}{l}\text { Korelasi kuat, } \\
\text { dan signifikan }\end{array}$ & -.039 & .838 & $\begin{array}{ll}\text { Korelasi } & \text { tidak } \\
\text { kuat, dan } & \text { tidak } \\
\text { signifikan } & \end{array}$ \\
\hline 12. & Peran Dinas & -.078 & .682 & $\begin{array}{ll}\text { Korelasi } & \text { tidak } \\
\text { kuat, dan } & \text { tidak } \\
\text { signifikan } & \end{array}$ & -.192 & .308 & $\begin{array}{ll}\text { Korelasi } & \text { tidak } \\
\text { kuat, dan } & \text { tidak } \\
\text { signifikan } & \end{array}$ \\
\hline 13. & Peran Paguyuban & .462 & .010 & $\begin{array}{lr}\begin{array}{l}\text { Korelasi } \\
\text { kuat } \\
\text { signifikan }\end{array} & \text { dan } \\
\end{array}$ & -.177 & .350 & $\begin{array}{ll}\text { Korelasi } & \text { tidak } \\
\text { kuat, dan } & \text { tidak } \\
\text { signifikan } & \end{array}$ \\
\hline
\end{tabular}

Sumber : Hasil Analisis Tim Peneliti

Tabel 3 : Analisis Faktor Berpengaruh Terhadap Keberhasilan Stabilisasi PKL

\begin{tabular}{|c|c|c|c|c|c|}
\hline \multirow[t]{2}{*}{ aktor } & \multirow[t]{2}{*}{ Variabel } & \multicolumn{3}{|c|}{$\begin{array}{l}\text { Extraction } \\
\text { Sums of Squared } \\
\text { Loadings }\end{array}$} & \multirow[t]{2}{*}{ Analisis } \\
\hline & & Total & $\begin{array}{c}\text { \% of } \\
\text { Varianc } \\
\text { e }\end{array}$ & $\begin{array}{c}\text { Cumulativ } \\
\text { e } \%\end{array}$ & \\
\hline
\end{tabular}




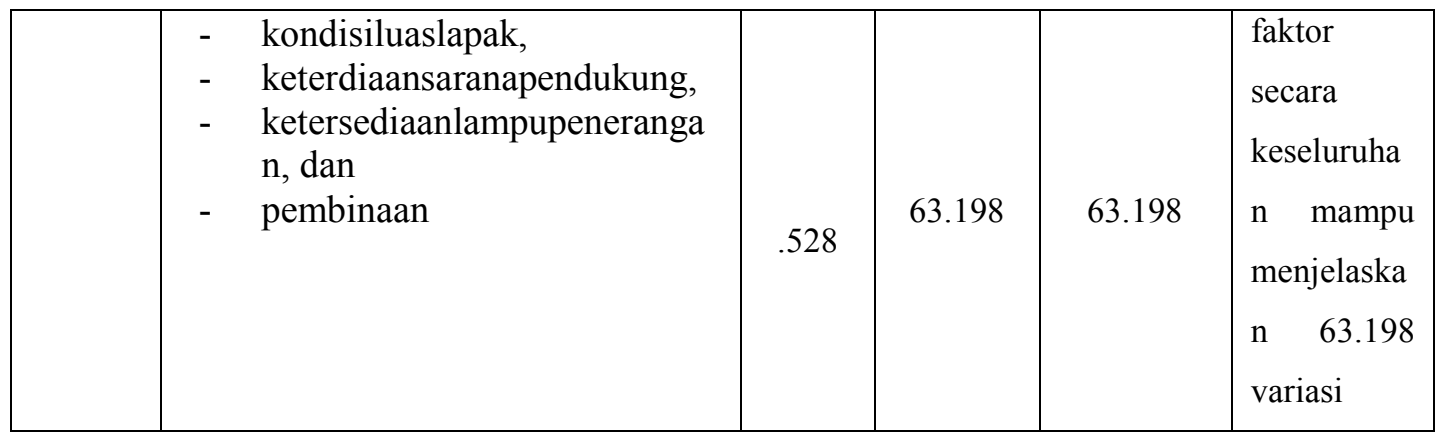

Tabel 4 : Analisis Faktor Berpengaruh Terhadap Keberhasilan Relokasi PKL

\begin{tabular}{|c|c|c|c|c|c|}
\hline \multirow[t]{2}{*}{$\begin{array}{c}\text { akt } \\
\text { or }\end{array}$} & \multirow[t]{2}{*}{ Variabel } & \multicolumn{3}{|c|}{$\begin{array}{c}\text { Extraction } \\
\text { Sums of Squared } \\
\text { Loadings } \\
\end{array}$} & \multirow[t]{2}{*}{ Analisis } \\
\hline & & Total & $\begin{array}{c}\% \text { of } \\
\text { Variance }\end{array}$ & $\begin{array}{c}\text { Cumulative } \\
\%\end{array}$ & \\
\hline & $\begin{array}{ll}\text { - } & \text { Kondisisarana, } \\
\text { - } & \text { polapengelompokkan, } \\
\text { - } & \text { keberadaanfungsiutam } \\
& \text { a, dan } \\
\text { - } & \text { aglomerasi }\end{array}$ & .944 & 058 & 58 & \multirow{2}{*}{$\begin{array}{ll}\text { - } & \text { Faktor } 1 \\
& \text { mampumenjelaska } \\
\text { n } 42.058 \% \text { variasi } \\
\text { - } & \text { Faktor } 2 \\
& \text { mampumenjelaska } \\
\text { n } 20.394 \% \text { variasi } \\
\text { - } & \text { Keduafaktorkeselu } \\
& \text { ruhanmampumenj } \\
\text { elaskan } 62.452 \\
\text { variasi }\end{array}$} \\
\hline & $\begin{array}{ll}- & \text { ketersediaanparkir, } \\
\text { - } & \text { ketersediaanair bersih, } \\
\text { - } & \text { estetikalokasi }\end{array}$ & .428 & 20.394 & 62.452 & \\
\hline
\end{tabular}

